\title{
Pesquisas: prioridades para a nossa saúde pública
}

\section{Research: priorities to our public health}

São Paulo, 23 de junho de 2008.

Prezado Editor,

O título parece estranho: muitos de nossos problemas de saúde pública no País já foram cientificamente equacionados há bastante tempo; falta destinar o que conhecemos à prática assistencial. Esta aplicação, no entanto, também precisa ser mais bem embasada em pesquisas. Temos exemplos que mostram como estudos deste tipo podem permitir melhores custo/benefício e ações.

Um é a prevenção da rubéola congênita. A vacina é muito eficiente e de pequeno risco, mas há um preço a pagar para vacinar toda a população. Assim que a vacina ficou disponível foram propostas táticas para coibir a citada conseqüência da doença, extremamente preocupante em virtude da intensidade de distúrbios que pode provocar. Algumas demonstraram utilidade, mas o resultado desejado, ou seja, controle definitivo do mal, não chegou a ser obtido. Impõe-se a realização de estudos subseqüentes a fim de definir conduta satisfatória globalmente; contudo, aguardamos bons projetos, recursos suficientes inclusive provenientes de órgãos financiados de pesquisas e participação de pesquisadores satisfeitos.

Existem outras situações de problemas comuns na prática médica que exigiram investigações. Por exemplo, é necessário fazer exames parasitológicos de fezes de rotina em crianças, cujo rendimento não é grande coisa, ou é mais fácil dar periodicamente uma droga que seja capaz de atingir a grande maioria dos vermes, já que temos remédios muito seguros e com poucos efeitos colaterais. Esta é matéria que mereceria também moldes matemáticos ou até avaliações comparativas.

A fortificação de alimentos com ferro é custo/efetiva em locais como São Paulo, onde anemia por deficiência alimentar não é tão freqüente e onde temos pessoas com talassemia minor, além de outras hemoglobinopatias, prejudicáveis pela citada conduta; vale então especular sobre este tema.

Mais relevantes talvez sejam problemas não bem equacionados cientificamente e para os quais temos tomado atitudes empíricas. A situação da dengue no Brasil sugere - mas não somos dogmáticos nisto - que a única solução razoável é uma vacina. Estamos confessando não considerar possível, hoje, o que já foi feito no Brasil no começo do século 20, sem inseticidas e sem os recursos modernos, por Oswaldo Cruz, na própria cidade do Rio de Janeiro. Ele acabou com o mosquito transmissor, em outra época e em outras condições. Podemos estar errados - mas a vacina seria algo muito mais aplicável, se existisse. Deveríamos estar investigando mais para consegui-la. Ainda em relação a doenças transmitidas pelo Aedes aegypti, observamos casos de febre amarela de origem vacinal, o que não era bem conhecido antes da vacinação em massa efetuada no Brasil. Por que ocorrem estes casos e qual o risco exato? Não sabemos e, sem averiguações adequadas, continuaremos sem saber.

Para tentar debelar a infecção devida ao Tripanosoma cruzi, protozoário causador da doença de Chagas, tradicional endemia brasileira, só contamos com dois fármacos atualmente. Todavia, apesar de úteis, sobretudo em determinadas circunstâncias, não são os remédios desejados. O citado parasita hoje praticamente não é mais transmitido, no Brasil, pelo "barbeiro". Aconteceu a propósito grande sucesso, devido à vontade política, à programação preventiva bem planejada e à execução elogiável. Ainda existem no País, convém lembrar, pelo menos dois milhões e quinhentos mil acometidos no território nacional e o problema está aumentado na Amazônia. Outrossim, adquirem cada vez mais visualização modos alternativos de veiculação do protozoário. Precisamos, então, de novos medicamentos. Universidades e indústrias farmacêuticas têm a obrigação de reconhecer que suas capacidades devem respeitar prioridades.

Nossos índices de violência urbana levam a grandes problemas de saúde pública; deveríamos incentivar trabalhos sociológicos que definam melhor onde agir. As respostas automáticas tipo "põe mais polícia" ou "encarrega o capitão Nascimento de resolver isto" não têm dado certo - como não tem funcionado a sociologia de botequim de pôr toda a culpa da violência na sociedade e considerar o "meliante" um pobre coitado - na verdade é um coitado que quer deixar de ser pobre por métodos heterodoxos... Isto na diminuição da causa básica da violência. Todavia também precisamos amoldar o atendimento às vítimas de maneira mais adequada e custo/efetiva. Equipar prefeituras com ambulâncias, que é o que mais tem sido feito, não 
deve ser o melhor método de lidar com a situação - a menos que façam algum tipo de particularização que documente sua utilidade.

Outro assunto que pede avaliação científica é a gestão dos recursos que temos em saúde pública. Copiamos para o nosso Sistema Único de Saúde (SUS) um modelo inglês que decididamente não funciona do mesmo modo em ambiente tropical. Lá um paciente passa primeiro pelo médico clínico geral e só, com esta conduta, ele é encaminhado a especialistas; aqui nossos postos de saúde dão atendimento, quando dão, precário. A população percebe bem o fato e vira-se como pode, o que leva à pletora de clientela em hospitais universitários. Estes, por atenderem melhor, afogam-se na demanda.

Enfim, há muito para catalogar e investigar nos nossos problemas de saúde pública, até porque se não o fizermos, ninguém os fará e vamos continuar copiando normas de outros lugares. Pode até dar certo de vez em quando, mas na nossa visão, bem de vez em quando.

Como mensagem final incitamos a preferência, no campo da investigação científica, à busca de amparos à saúde pública no Brasil. Núcleos universitários, instituição congêneres, o Ministério da Saúde e especialmente órgãos financiadores de pesquisas têm que se comprometer com o esteio à busca de conhecimentos aptos a vaticinar eliminação ou diminuição de problemas médico-sanitários, até mesmo elaborando elenco de estudos preferenciais.

Vicente Amato Neto Jacyr Pasternak Instituto de Medicina Tropical de São Paulo, Faculdade de Medicina, Universidade de São Paulo 